\title{
The extraction of zinc from chloride solutions using dibutyl butylphosphonate (DBBP) in Exxsol D100 ${ }^{(\bullet)}$
}

\author{
F.J. Alguacil $\left(^{(*)}\right.$, B. Schmidt $(* *)$, R. Mohrmann ${ }^{(* *)}$ and E. Giebel ${ }^{(* *)}$ \\ Abstract The reaction of zinc chloride with dibutyl butylphosphonate in Exxsol D100 has been studied. The \\ distribution coefficient of zinc is independent of equilibrium $\mathrm{pH}$, thus, suggesting a solvation \\ extraction reaction. Experimental data indicate that this reaction is exothermic $\left(\Delta \mathrm{H}^{\circ}=-28.4 \mathrm{~kJ} / \mathrm{mol}\right)$. \\ Slope analysis for the system at various DBBP concentrations reveals the formation in the loaded \\ organic phases of species which probable 1:2 (Zn:DBBP) stoichiometries. This was confirmed by \\ results obtained at full DBBP Zn-loading capacity. The stoichiometric factor of water in the \\ extraction reaction is found to be 4 , whereas experimental data also indicated that two chloride ions \\ are involved for each metal extracted, resulting in a $\mathrm{ZnCl}_{2} \cdot 2 \mathrm{~L} \cdot 4 \mathrm{H}_{2} \mathrm{O}$ stoichiometry (L represents the \\ extractant).
}

Keywords: Solvent extraction. Zinc. Chloride. Phosphonates.

\section{La extracción de zinc de disoluciones en medio cloruro mediante dibutil butilfosfonato (DBBP) en Exxsol D100}

\begin{abstract}
Resumen Se estudia la extracción de zinc, en medio cloruro, con el dibutil butilfosfonato disuelto en Exxsol D100. El coeficiente de distribución del metal es independiente del $\mathrm{pH}$ de equilibrio de la fase acuosa, lo que sugiere un mecanismo de extracción por solvatación. Los resultados experimentales indican que la reacción es exotérmica $\left(\Delta \mathrm{H}^{\circ}=-28,4 \mathrm{~kJ} / \mathrm{mol}\right)$. Mediante análisis de la pendiente obtenida cuando se emplean distintas concentraciones de DBBP en la extracción de zinc se deduce la formación de una especie con estequiometria 1:2 (Zn:DBBP) en la fase orgánica. Este hecho se confirma con los resultados obtenidos cuando se satura completamente la fase orgánica. En esta fase, el factor estequiométrico para el agua es 4, mientras que para el ion cloruro es 2, por lo que la especie extraida tiene una estequiometria final representada por $\mathrm{ZnCl}_{2} \cdot 2 \mathrm{~L} \cdot 4 \mathrm{H}_{2} \mathrm{O}$ (L representa al agente de extracción).
\end{abstract}

Palabras clave: Extracción con disolventes. Zinc. Cloruro. Fosfonatos.

\section{INTRODUCTION}

In recent years the recovery of metals from aqueous chloride solutions has attracted much attention and the development of solvent extraction technology has increased the possibility of metal beneficiation by hydrometallurgical processes. This technology is in widespread use for the recovery and purification

(•) Trabajo recibido el día 5 de marzo de 1999 y aceptado en su forma final el 7 de julio de 1999.

(*) Centro Nacional de Investigaciones Metalúrgicas, CENIM (CSIC). Avda. Gregorio del Amo, 8. 28040Madrid (España).

(**) BFI. Düsseldorf (Alemania).

$(* * *)$ E. Giebel. Dudelange (Luxemburgo). of copper form acidic, mainly sulphate, leach solutions with hydroxyoximes (1).

The recovery of zinc(II) from chloride solutions using solvent extraction technology is also of particular interest and various extractants had been investigated (Table I).

The aim of the present work was to study the reaction of zinc, with DBBP diluted in Exxsol D100, from aqueous chloride solutions in order to identify the stoichiometry of extracted species and to contribute to the understanding of the chemistry of such systems and their possibilities in the recovery of zinc from various chloride solutions, e. g. waste streams from hot galvanizing or zinc electroplating processes. 
TABLE I.- Solvent extraction systems for zinc extraction from chloride systems

TABLE I.- Sistemas de extracción con disolventes empleados en la extracción de zinc de disoluciones en medio cloruro

\begin{tabular}{|l|l|c|}
\hline Extractant type & \multicolumn{1}{|c|}{ Reagent } & Reference \\
\hline Acid & Kelex 100 & 2 \\
& Carboxylic acids & 3 \\
& DEHPA & 4,5 \\
& CYANEX 302 & 6,7 \\
\hline Basic & Secondary amines & 8 \\
& Aliquat 336 & 9 \\
\hline Neutral & TBP & 10 \\
& DPPP & 11 \\
& Acorga ZNX50 & 12 \\
\hline
\end{tabular}

\section{EXPERIMENTAL METHOD}

The extractant DBBP was obtained from Albrigt and Wilson Inc., and was used without further purification. Exxsol D100, using as diluent of the organic phase, was obtained from Exxon Chem. Iberia, its characteristics are: boiling range 234$264^{\circ} \mathrm{C}$, flash point $99^{\circ} \mathrm{C}$, aromatics content 0.9 , density $\left(15^{\circ} \mathrm{C}\right) 0.816 \mathrm{~g} / \mathrm{cm}^{3}$. All other chemicals were of AR grade.

Experiments were carried out by the next procedure. Measured amounts of the aqueous and organic phases were placed in separatory funnels provided with mechanical shaking $\left(600 \mathrm{~min}^{-1}\right)$ and thermostatted at the required temperature. Agitation was applied for $15 \mathrm{~min}$ as previous experiments showed that this time was sufficient to achieve equilibrium. All experiments were conducted at an $\mathrm{O} / \mathrm{A}$ phase ratio of 1 and the organic solutions were of $50 \% \mathrm{v} / \mathrm{v}$ DBBP in Exxsol D100 unless otherwise noted. After settling, the zinc content in the equilibrated aqueous solutions was analysed by AAS. Metal in the organic phase was calculated by mass balance.

\section{RESULTS AND DISCUSSION}

The distribution coefficient $D$ is defined as the ratio of total metal concentration in the organic phase to the total metal concentration in the aqueous phase.

\subsection{Influence of the $\mathrm{pH}$ on the extraction of zinc}

Two series of experiments were performed to examine the effect of $\mathrm{pH}$ on zinc extraction. In the first series of experiments, the aqueous feed, with various $\mathrm{pH}$ values adjusted with $\mathrm{HCl}$, contained 1.0 $\mathrm{g} / \mathrm{L}$ of zinc. The results are given in figure 1 . In the other case, the aqueous solutions contained $1.0 \mathrm{~g} / \mathrm{L}$ of zinc and $7 \mathrm{~mol} / \mathrm{L}$ of $\mathrm{Cl}^{-}$, adding as $\mathrm{CaCl}_{2}$. Figure 1 also shows the effect of $\mathrm{pH}$ on metal extraction. In both cases, temperature was of $20^{\circ} \mathrm{C}$.

The extraction of zinc is independent of aqueous $\mathrm{pH}$, being this result similar to that obtained with phosphonates but not when using TBP (11 and 13).

\subsection{Influence of chloride ion on zinc extraction}

From results shown above it is clear that the presence of $\mathrm{CaCl}_{2}$ in the aqueous feed greatly improves the extraction of zinc by DBBP. To obtain further information on this behaviour, experiments were conducted with aqueous solutions of $1.0 \mathrm{~g} / \mathrm{L}$ zinc and various contents of chloride ion, added as $\mathrm{CaCl}_{2}$. Results were presented in table II. It can be seen that the increase of the anion concentration in the aqueous feed increases the extraction of zinc.

\subsection{Influence of temperature}

The study of the influence of this variable on zinc extraction by DBBP was carried out using aqueous feed of $1.0 \mathrm{~g} / \mathrm{L}$ zinc and $7 \mathrm{~mol} / \mathrm{L} \mathrm{Cl}^{-}$(added as $\mathrm{CaCl}_{2}$ ). Temperature was varied in the range 10-50 ${ }^{\circ} \mathrm{C}$. Results obtained are presented in figure 2, plotting $\log D_{\mathrm{Zn}}$ versus $1000 / T$, it can be seen that

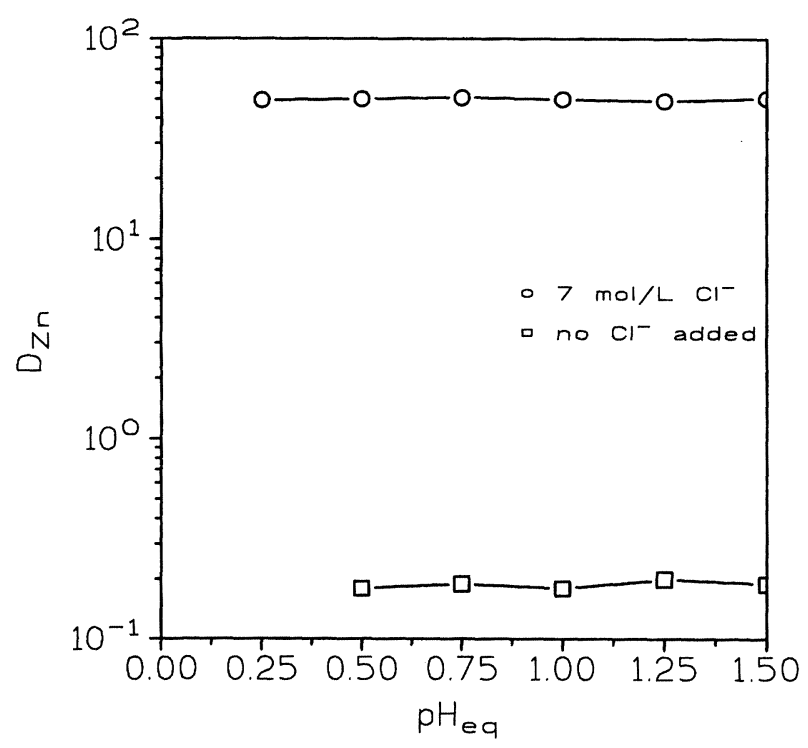

FIG. 1.- Influence of $\mathrm{pH}$ on the extraction of zinc by DBBP.

FIG. 1.- Influencia del $p H$ en la extracción de zinc mediante $D B B P$. 
TABLE II.- The effect of $\mathrm{Cl}^{-}$on zinc extraction by DBBP

TABLA II.- El efecto de la presencia de $\mathrm{Cl}^{-}$sobre la extracción de zinc mediante DBBP

\begin{tabular}{|c|c|}
\hline Chloride concentration, $\mathrm{mol} / \mathrm{L}$ & $D_{\mathrm{Zn}}$ \\
\hline 1.5 & 1.99 \\
3.5 & 7.94 \\
7.0 & 49.4 \\
\hline
\end{tabular}

$\mathrm{pH}_{\mathrm{eq}}: 0.5$.

Temperature: $20^{\circ} \mathrm{C}$.

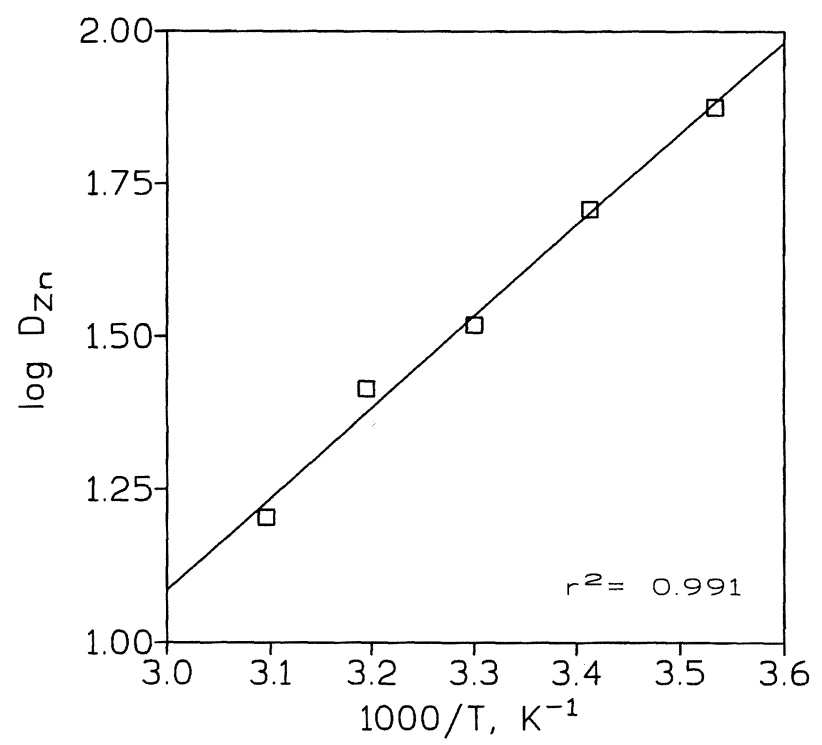

FIG. 2.- Arrhenius plot for zinc extraction by DBBP.

FIG. 2.- Representación de Arrhenius para la extracción de zinc mediante $D B B P$

the increase of temperature decreases zinc extraction, although phase separation is good even at lower temperatures. From this figure is obtained that $\Delta \mathrm{H}^{\circ}$ is $-28.4 \mathrm{~kJ} / \mathrm{mol}$, the reaction is exothermic.

\subsection{Extraction mechanism}

DBBP is a solvating extractant (14) and considering the results obtained above, e.g. the extraction is independent of aqueous $\mathrm{pH}$ and the positive influence of chloride ion on zinc extraction, the extraction reaction can be generalized as:

$$
\mathrm{Zn}_{\mathrm{aq}}^{2+}+2 \mathrm{Cl}_{\mathrm{aq}}^{-}+\mathrm{qL}_{\mathrm{org}} \Leftrightarrow \mathrm{ZnCl}_{2} \cdot \mathrm{qL}_{\mathrm{org}}
$$

where $\mathrm{L}$ represents the extractant molecule and aq and org the respective aqueous and organic phases. On the other hand, and considering the solvating characteristics of DBBP it can be assumed that water molecules also enter the metal-DBBP extracted species.

The equilibrium constant for the above reaction can be expressed, in terms of activities, as:

$$
k_{\text {ext }}=\frac{\left[\mathrm{ZnCl}_{2} \cdot \mathrm{qL}\right]_{\mathrm{org}}}{\left[\mathrm{Zn}^{2+}\right]_{\mathrm{aq}}\left[\mathrm{Cl}^{-}\right]_{\mathrm{aq}}^{2}[\mathrm{~L}]_{\mathrm{org}}^{\mathrm{q}}}
$$

and for zinc speciation in the aqueous solution:

$$
\begin{aligned}
{[\mathrm{Zn}]_{\mathrm{T}} } & =\left[\mathrm{Zn}^{2+}\right]+\left[\mathrm{ZnCl}^{+}\right]+\left[\mathrm{ZnCl}_{2}\right]+ \\
& +\left[\mathrm{ZnCl}_{3}^{-}\right]+\left[\mathrm{ZnCl}_{4}^{2-}\right]
\end{aligned}
$$

The formation constant for the above complexes is defined as:

$$
\beta_{\mathrm{n}}=\frac{\left[\mathrm{ZnCl}_{\mathrm{n}}^{2-\mathrm{n}}\right]}{\left[\mathrm{Zn}^{2+}\right]\left[\mathrm{Cl}^{-}\right]^{\mathrm{n}}}
$$

where $\mathrm{n}$ varies from 1 to 4 .

By substituting, eq. [3] becomes:

$$
[\mathrm{Zn}]_{\mathrm{T}}=\left[\mathrm{Zn}^{2+}\right]\left(1+\Sigma \beta_{\mathrm{n}}\left[\mathrm{Cl}^{-}\right]^{\mathrm{n}}\right)
$$

The substitution of eq. [5] into eq. [2] and considering the definition of $D_{\mathrm{Zn}}$ gives:

$$
k_{\text {ext }}\left[\mathrm{Cl}^{-}\right]^{2}\left(1+\sum \beta_{\mathrm{n}}\left[\mathrm{Cl}^{-}\right]^{\mathrm{n}}\right)=\frac{D_{\mathrm{Zn}}}{[L]_{\mathrm{org}}^{\mathrm{q}}}
$$

Results of extraction experiments at $20^{\circ} \mathrm{C}$ are presented in table III. In all the cases the total chloride ion concentration in the aqueous solution was maintained at $7 \mathrm{~mol} / \mathrm{L}$, and considering that the amounts of zinc and chloride extracted are much smaller than the amounts of water and $\mathrm{Cl}^{-}$, the activities of both water and chloride ion can thus be considered as constant.

Equation (6) can be rewritten as:

TABLE III.- The influence of DBBP on zinc extraction

TABLA III.- La influencia de la concentración de $D B B P$ sobre la extracción de zinc

\begin{tabular}{|c|c|}
\hline DBBP, \% v/v & $D_{\mathrm{Zn}}$ \\
\hline 1 & 0.002 \\
2.5 & 0.013 \\
5 & 0.046 \\
7.5 & 0.11 \\
10 & 0.19 \\
\hline
\end{tabular}

Aqueous phase: $1.0 \mathrm{~g} / \mathrm{L} \mathrm{Zn}$ in $7 \mathrm{~mol} / \mathrm{L} \mathrm{Cl}^{-}$. $\mathrm{pH}_{\mathrm{eq}}: 0.5 \pm 0.02$. 


$$
\log D_{\mathrm{Zn}}=\log K_{\mathrm{ext}}+q \log [L]
$$

where $K_{\text {ext }}$ is an effective extraction constant defined as:

$$
K_{\text {ext }}=k_{\text {ext }}\left[\mathrm{Cl}^{-}\right]^{2}\left(1+\Sigma \beta_{\mathrm{n}}\left[\mathrm{Cl}^{-}\right]^{\mathrm{n}}\right)
$$

A plot of $\log D_{\mathrm{Zn}}$ versus $\log [\mathrm{DBBP}]_{\text {org }}$ will give a straight line of slope $q$. The equilibrium zinc concentration in the equilibrated organic solutions is much smaller than the initial extractant concentration, thus, it can be assumed that the equilibrium DBBP concentration in the organic phase is equal to the initial reagent concentration and at lower extractant concentrations the activities can be considered equal to the concentrations. By plotting $\log D_{\mathrm{Zn}}$ against $\log [\mathrm{DBBP}]_{\text {org }}$, as shown in figure 3 , a straight line of slope 2 is obtained, thus the coefficient $q$ of eq. [1] can be considered 2 and the value of $\log K_{\text {ext }}$ being 0.19 .

The possibility of extractant dimers formation at higher DBBP concentrations should result in a slope different than 2 either if the extraction constant remained unaletered or changed with the formation of dimers. On the other hand, it was found that the viscosity of the loaded DBBP organic phases increases with the loading of zinc into the organic solutions.

The formation of zinc chlorocomplexes can be written as:

$$
\mathrm{ZnCl}_{\mathrm{n}-1}^{3-\mathrm{n}}+\mathrm{Cl}^{-}=\mathrm{ZnCl}_{\mathrm{n}}^{2-\mathrm{n}}
$$

where the overall constant, $K_{\mathrm{n}}$, is defined as:

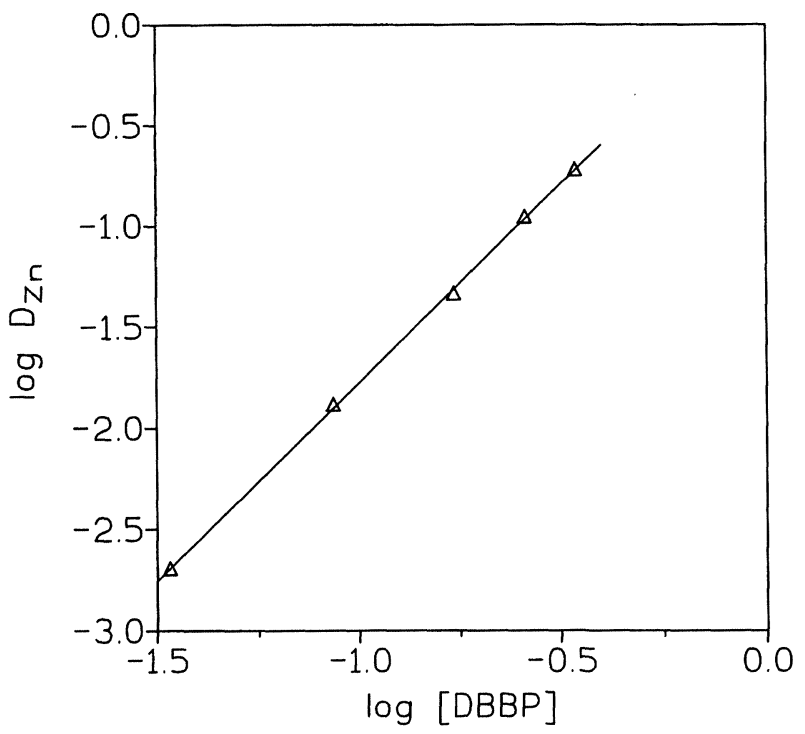

FIG. 3.- Variation of zinc extraction with initial DBBP concentracion. Temperature $20^{\circ} \mathrm{C}$.

FIG. 3.- Variación de la extracción de zinc con la concentración de DBBP. Temperatura $20^{\circ} \mathrm{C}$.

$$
K_{\mathrm{n}}=\frac{\left[\mathrm{ZnCl}_{\mathrm{n}}^{2-\mathrm{n}}\right]}{\left[\mathrm{ZnCl}_{\mathrm{n}-1}^{3-\mathrm{n}}\right]\left[\mathrm{Cl}^{-}\right]}
$$

where $n$ changes from 1 to 4 . The reported values of the respective constants $\left(K_{1}\right.$ through $\left.K_{4}\right)$ varied. In any case, $\mathrm{ZnCl}_{2}$ should not be the predominant species in the solution at certain chloride concentrations. On the other hand, the $1: 2\left(\mathrm{Zn}: \mathrm{Cl}^{-}\right)$ is the major species that DBBP can extracts. It is a fact that independent of which species of zinc is extracted, at chloride ion activities constant, the slope analysis can be carried out because the kinetics of eq. [9] are fast and, thus, there is a redistribution of the zinc species in favour of the $1: 2$ species.

A number of experiments was carried out to saturate the organic solution with zinc. The initial concentration of DBBP in the organic solution was $50 \% \mathrm{v} / \mathrm{v}$, while the zinc concentration in the initial aqueous solution varied from 0.5 to $180 \mathrm{~g} / \mathrm{L}$. In all the cases the total $\mathrm{Cl}^{-}$concentration was maintained constant at $7 \mathrm{~mol} / \mathrm{L}$ by addition of $\mathrm{CaCl}_{2}$. The results are shown in table IV, from which molar ratios concentrations of DBBP to zinc in the organic phase were calculated and plotted against the zinc equilibrium concentration in the raffinate (Fig.4).

The molar ratio $\mathrm{DBBP} /[\mathrm{Zn}]$ in the organic solution decreases to near 2 when the metal concentration in the aqueous feed increases to near

TABLE IV.- Zinc extraction by DBBP at various metal initial concentrations

TABLA IV.- Extracción de zinc mediante DBBP a distintas concentraciones iniciales del metal

\begin{tabular}{|c|c|c|}
\hline Zinc initial, g/L & $\begin{array}{c}\text { Zinc aqueous } \\
\text { phase, } \mathrm{g} / \mathrm{L}\end{array}$ & $\begin{array}{c}\text { Zinc organic } \\
\text { phase, } \mathrm{g} / \mathrm{L}\end{array}$ \\
\hline 0.5 & 0.01 & 0.49 \\
1.0 & 0.02 & 0.98 \\
2.5 & 0.05 & 2.45 \\
5.0 & 0.1 & 4.90 \\
10.0 & 0.42 & 9.58 \\
20.0 & 3.81 & 16.19 \\
50.0 & 19.0 & 31.0 \\
75.0 & 35.1 & 39.9 \\
100.0 & 52.9 & 47.1 \\
120.0 & 67.8 & 52.2 \\
135.0 & 79.3 & 55.7 \\
150.0 & 91.1 & 58.9 \\
160.0 & 99.7 & 60.3 \\
170.0 & 109.5 & 60.5 \\
180.0 & 119.6 & 60.4 \\
\hline
\end{tabular}

Temperature: $20^{\circ} \mathrm{C}$. $\mathrm{pH}_{\mathrm{eq}}: 0.5 \pm 0.02$ 


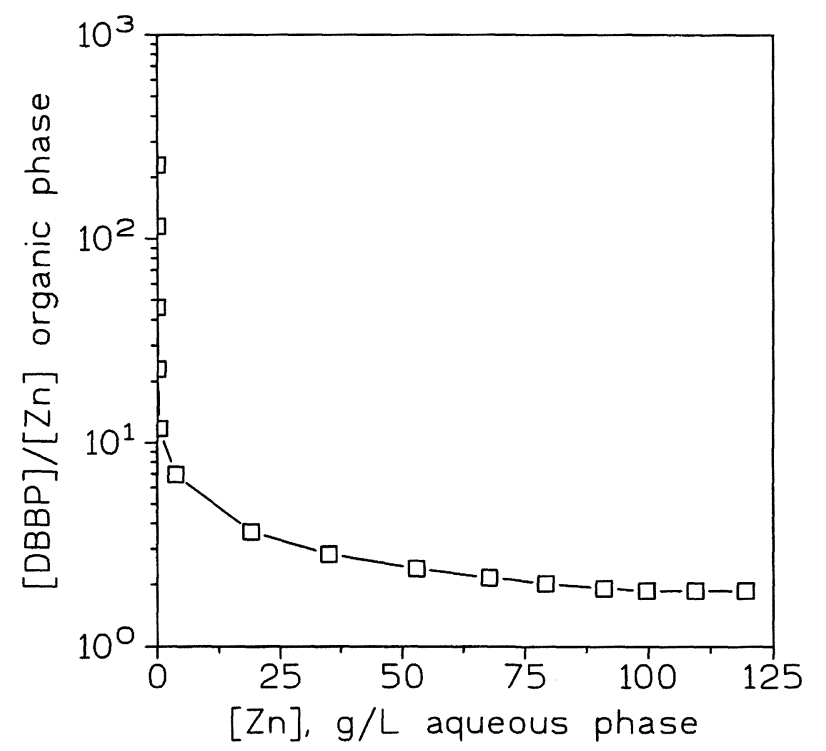

FIG. 4.- Influence of zinc concentration in the aqueous feed on the molar ratio $[\mathrm{DBBP}] /[\mathrm{Zn}]$ in the organic phase.

FIG. 4.- Influencia de la concentración de zinc en la fase acuosa en la relación molar [DBBP]/[Zn] en la fase orgánica.

$100 \mathrm{~g} / \mathrm{L}$. Further increases of zinc concentration in the aqueous solution do not decrease this ratio, because DBBP has reached its maximum loading capacity.

The corresponding zinc equilibrium loading isotherm is shown in figure 5 . The isotherm can be mathematically described by the equation:

$$
[\mathrm{Zn}]_{\mathrm{org}}=\frac{73.09[\mathrm{Zn}]_{\mathrm{aq}}}{24.96+[\mathrm{Zn}]_{\mathrm{aq}}}
$$

where $[\mathrm{Zn}]_{\text {org }}$ and $[\mathrm{Zn}]_{\mathrm{aq}}$ represented the corresponding zinc concentrations at equilibrium in the respective organic and aqueous phases.

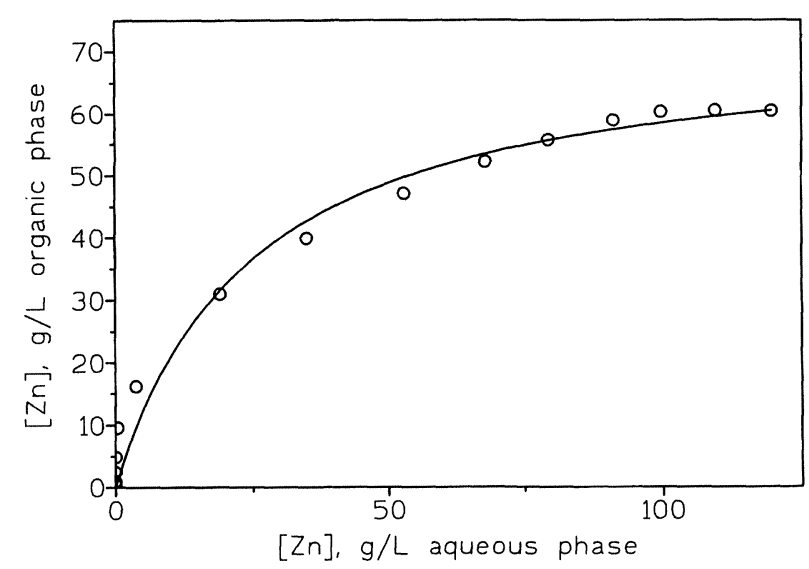

FIG. 5.- Zinc loading equilibrium isotherm. Temperature: $20^{\circ} \mathrm{C}$.

FIG. 5.- Isoterma de extracción de zinc. Temperatura: $20^{\circ} \mathrm{C}$.
The stoichiometric factor of chloride ion in this system was estimated by varying the chloride ion concentration from 1 to $3.5 \mathrm{~mol} / \mathrm{L}$ by $\mathrm{CaCl}_{2}$ addition. As preliminary IR studies had shown, the possibility of finding water associated with the extracted species can not be neglected, thus a water stoichiometric factor was also estimated considering that the activity of water varies with the chloride ion concentration.

The activity coefficient of chloride ion was obtained from reported data ( 15 y 16$)$, whereas the activity of water was determined accordingly with the literature (17 y 18). The results are given in table V.

Plots of $\log D_{\mathrm{Zn}}$ versus $\left(2 \log a_{\mathrm{Cl}}+\mathrm{b} \log a_{\mathrm{H} 2 \mathrm{O}}\right)$ were made using different $b$ values. With $b=4$, the plot can be represented by a straight line with slope near to 1 , as shown in figure 6 . Thus, the stoichiometry of the extracted species can be represented by $\mathrm{ZnCl}_{2} \cdot 2 \mathrm{~L} \cdot 4 \mathrm{H}_{2} \mathrm{O}$. It is estimated that the hydration number of zinc chloride is 10-15 (19), during the extraction of zinc by DBBP (20), a number of water molecules in the primary coordination layer of zinc chloride are replaced by DBBP molecules, remaining only 4 water molecules coordinated with zinc.

\section{CONCLUSIONS}

The extraction of zinc from chloride solutions using DBBP dissolved in Exxsol D100 has been studied. The extraction is independent of aqueous $\mathrm{pH}$ but dependent on the presence of chloride ions in the aqueous media, a solvation reaction is suggested. This reaction is exothermic $\left(\Delta \mathrm{H}^{\circ}=-28.4 \mathrm{~kJ} / \mathrm{mol}\right)$. Slope analysis indicated that the stoichiometric factor between $\mathrm{Zn}$ and the extractant is $1: 2$ ( $\mathrm{Zn}: \mathrm{DBBP})$, this has been confirmed at maximum zinc load of the DBBP organic solution. The equilibrium loading isotherm has been obtained at $20^{\circ} \mathrm{C}$. The experimental data indicate that the stoichiometric factor for chloride and water in the

TABLE V.- Activities of chloride ion and water at different chloride ion concentrations

TABLA V.- Actividades de los iones cloruro y agua a varias concentraciones de ion cloruro

\begin{tabular}{|c|c|c|}
\hline $\mathrm{Cl}^{-}, \mathrm{mol} / \mathrm{L}$ & $a \mathrm{Cl}^{-}$ & $a \mathrm{H}_{2} \mathrm{O}$ \\
\hline 1.0 & 0.604 & 0.989 \\
1.5 & 0.875 & 0.977 \\
2.0 & 1.146 & 0.929 \\
2.5 & 1.422 & 0.910 \\
3.0 & 1.707 & 0.885 \\
3.5 & 2.000 & 0.857 \\
\hline
\end{tabular}

Rev. Metal. Madrid, 35 (4), 1999259

http://revistademetalurgia.revistas.csic.es 


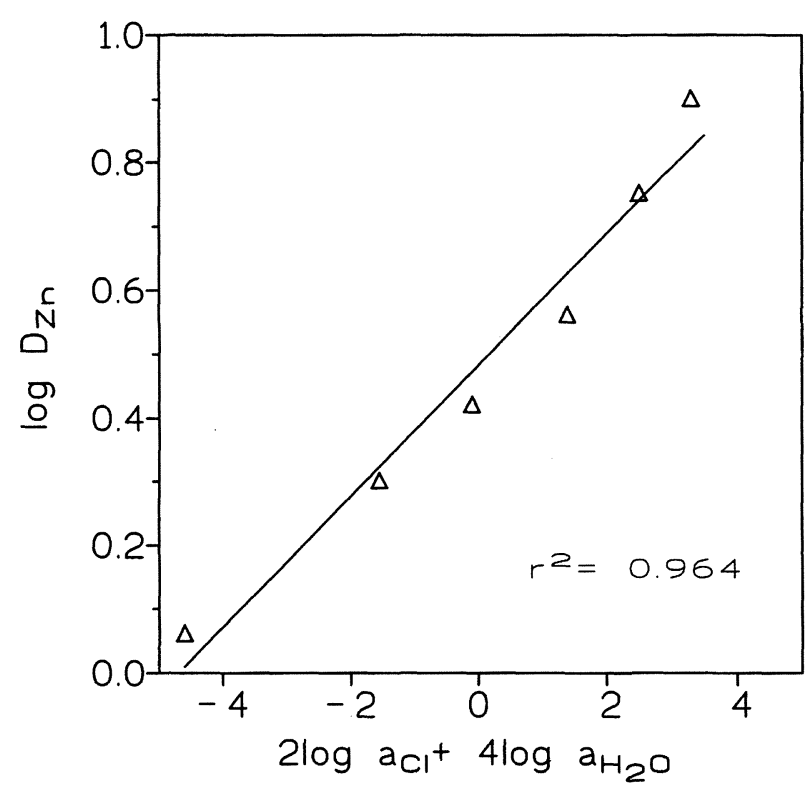

FIG. 6. - Plot of $\log D_{\mathrm{Zn}}$ vs $2 \log a_{\mathrm{Cl}}+4 \log a_{\mathrm{H} 2 \mathrm{O}}$.

FIG. 6.- Representación de log $\mathrm{D}_{\mathrm{Zn}}$ frente a 2 log $\mathrm{a}_{\mathrm{Cl}}+4 \log \mathrm{a}_{\mathrm{H} 2 \mathrm{O}}$.

organic phase are 2 and 4 , respectively; thus, the final stoichiometry of the extracted species can be represented by $\mathrm{ZnCl}_{2} \cdot 2 \mathrm{~L} \cdot 4 \mathrm{H}_{2} \mathrm{O}$, being $\mathrm{L}$ the extractant.

\section{Acknowledgements}

Work was carried out with a financial grant from the European Coal and Steel Community (Project 7210-PR-031). F.J.A. also wishes to CICYT (Spain) for Project MAT98-1346-CE.

\section{REFERENCES}

(1) Szymanowski, J. Hydroxyoximes and Copper Hydrometallurgy, CRC Press, Boca Raton, 1992.

(2) Harrison, G., LaKshmanan, V.I. and Lawson, G.J. Hydrometallurgy, 1, 1976: 339-347.

(3) Verhaege, M. Hydrometallurgy, 1, 1975: 97-102.

(4) LI, Z.C. Hydrometallurgy, 16, 1986: 231-241.

(5) Amer, S., Luis, A., Cuadra, A. and Caravaca, C. Rev. Metal. Madrid, 30, 1994: 27-37.

(6) Alguacil, F.J., Сobo, A. and Caravaca, C. Hydrometallurgy, 31, 1992: 163-174.

(7) Benito, R., Menoyo, B. and Elizalde, M.P. Hydrometallurgy, 40, 1996: 51-63.

(8) Nakashio, F., Sato, H., Kondo, K. and Kawaho, Y. Solvent Extr. Ion Exch., 4, 1986: 757-770.

(9) Sato, T., Shimomura, T., Murakami, S., Maeda, T. and NAKAMURA, T. Hydrometallurgy, 12, 1984: 245-254.

(10) Ritcey, G.M., Lucas, B.H. and PRice, K.T. Hydrometallurgy, 8, 1982: 197-222.

(11) Nogueira, E.D. and Cosmen, P. Hydrometallurgy, 9, 1983: 333-347.

(12) Cote, G. and JAKUBiaK, A. Hydrometallurgy, 43, 1996: 277-286.

(13) Rice, N.M. and Sмiтh, M.R. Can. Metall. Q., 12, 1973: 341-349.

(14) Ritcey, G.M. and Ashbrook, A.W. Solvent Extraction., 1, Elsevier, Amsterdam, 1984.

(15) RoBinson, R.A. and STOKES, R.H. Electrolyte Solutions, Academic Press Inc., New York, 1955.

(16) Garrels, R.M. and Christ, C.L. Solution, Minerals and Equilibria, Harper \& Row, New York, 1965.

(17) Meissner, H.P. and Kusik, C.L. AIChE J., 18, 1972: 294 298.

(18) Kusik, C.L. and Meissner, H.P. Ind. Eng. Chem. Process Des. Dev., 12, 1973: 112-115.

(19) Bockris, J.O.M. and Reddy, A.K.N. Modern Electrochemistry, Plenum Press, New York, 1970.

(20) Lin, H.K., FANG, G.C. and RAO, P.D., EPD Congress'90, D.R. Gaskell (Ed.), TMS-AIME, Warrendale, 1990. 